Antea Helonia Efendi ${ }^{1}$, Moses Glorino Rumambo Pandin ${ }^{2}$

Universitas Airlangga

J1. Airlangga No.4 - 6, Airlangga, Kec. Gubeng, Surabaya, Jawa Timur, 60115

antea.helonia.efendi-2020@fib.unair.ac.id; moses.glorino@ fib.unair.ac.id

\title{
Book Review: \\ Filsafat Dan Kearifan Dalam Agama Dan Budaya Lokal \\ (Philosophy and Wisdom In Religion And Local Culture)
}

Syarif Hidayatullah, Abdul Rokhmat Sairah, Jirzanah, Lailiy Muthmainnah, Lasiyo, Reno Wikandaru, Septiana Dwiputri Maharani, Syafiq Effendhy; D.I Yogyakarta; 2020; 978-602-386-423-2; 305 PP.

Filsafat Dan Kearifan Dalam Agama Dan Budaya Lokal is written to improve the quality of research in the field of philosophy and the values of local wisdom, besides being able to describe, analyze, synthesize, interpret, evaluate, and reflect on various kinds of theories and practical problems in a philosophical perspective. Able to solve various problems in society philosophically. The book is also able to communicate philosophical ideas in writing and solve problems in social life.

A part of the results of research conducted by lecturers at the Faculty of Philosophy UGM who have diverse interests and expertise with the aim of being enjoyed by a wide audience of readers. Thus, academic thoughts and recommendations on various scientific, national and humanitarian issues resulting from research activities can be socialized and can be used as a reference and inspiration for various interested parties. Starting from academics, researchers, bureaucracy, to the general public.

The book presents a variety of new information for a wide audience which is packaged attractively through various aspects such as the relationship between philosophy and religion and philosophy with local culture. We know that philosophy with religion and local culture is very contradictory, but this book can answer that philosophy can link up with local culture and religion. The book needs to be reviewed because the information presented in this book is very interesting to review. Why is that? Because the book explores and explores local wisdom that exists in local culture and religion through a philosophical approach. A philosophical approach to scientific development can be done by exploring and developing philosophical aspects in the various branches of philosophy and science.

The book Filsafat Dan Kearifan Dalam Agama Dan Budaya Lokal meets the criteria of the needs of the audience (readers), because this book can answer and solve various problems in society philosophically and can carry out dialogue in solving problems in social life. The book also proves the role of philosophy in scientific development, examines philosophy and wisdom in religious aspects, and examines philosophy and wisdom in local culture.

In the book there is a lot of information that we get, such as in Chapter II contains two articles that attempt to investigate what ideas are contained in the emergence and development of economics and attempt to explain Islamic religious beliefs rationally to avoid blind beliefs that harm Muslims. Chapter III contains wisdom in the religious aspect which begins by examining the concept of Tao from the perspective of Chinese philosophy and religion, the concept of freedom that exists in Islamic teachings by using the Pancasila philosophy as a point of view (formal object) and seeing its possible relevance in the implementation of the Indonesian Unity Principles, then discusses metaphysical theology according to Confucianism, and the last one examines Islamic teachings on social justice using a philosophy of value perspective. The next chapter, Chapter IV discusses the work ethic of the Madurese community which has a very strategic position amid the stereotypes that have already been attached to the Madurese community, examining the principle of harmony with nature for the people of 
Ngadisari Village which does not have much difference with the Tengger Community in general, then local wisdom in preserving the environment in the contemporary era, and the latter explores the principles of Javanese society with the term "jembar segarane".

The book has a very positive influence on readers, namely, it can provide insight into the philosophy and scientific development, religion, and local culture. By reading the book it can fill our heads about some of the local cultures that exist in our country which are discussed in the book and we can find out the prophetic philosophy of Sheikh Muhammad Abduh which is different from philosophy, the truth of religion is absolute. Religion encompasses the knowledge that humans need regarding metaphysical subjects such as the existence of God and His attributes, life after death, and the purpose of creation for man and the universe.

The book is certainly very influential for the general public who reads this book because in it we are invited to think critically to answer problems that exist in society regarding the relationship between philosophy and religion. Philosophy and religion are two things that both offer and provide truth to humans. Philosophical truth is produced by the man himself. This happens because humans with existing minds can think critically about their realities and realities outside of themselves. In addition, the wisdom that is maintained in the local culture is unique in itself. In this way, the wisdom that has existed from a long time ago can be passed on to our children and grandchildren as a way of life despite experiencing conflicts in the waves of modernization and globalization, which are vulnerable for humans to leave their life guidelines that are considered good and will be abandoned because of the loss of care and empathy for others.

The book is proven to be able to describe, analyze, synthesize, interpret, evaluate, and reflect on various theories and practical problems from a philosophical perspective. Besides that, they can carry out research, apply research results and solve various problems in society in a philosophical manner. And what the researchers have produced is an effort to develop science by using the diversity of local wisdom that exists in the aspects of religion and local culture.

This is evident from the discussion in it which is reviewed in detail starting from the introduction which explains the research framework so that readers can understand the intent of the author, then the discussion contained in the book is also described very clearly and can answer the author's questions. In addition to answering the author's questions, this book also answers questions that exist in society such as the very diverse needs of the human economy. But this need, in the perspective of critical theorists and post-structuralists, is no longer "natural". Something that was not a human need was manipulated in such a way as to become a human need which eventually led to consumerism. This issue becomes important to discuss because, for the author, this issue raises a more serious problem.

"Now, when these needs are manipulated, even produced in the contemporary era, the economic behavior that has emerged is also increasingly" fierce "and worrying. History has proven that the efforts of mankind to sustain life and life so far have had a very serious impact on the environment. Global warming, climate change, rising sea levels, extinction of various species are a series of issues that adorn the mass media in this contemporary era. These various problems seem to show that human extinction is an insight. Humans are already on the brink of extinction, as a result of their behavior. Seeing the problems that have emerged lately, of course, humans must not remain silent and philosophy needs to take part in overcoming human problems in this contemporary era. Humans need to clean up and evaluate their behavior towards the environment so that the earth remains a comfortable home for mankind to live in, "pages 239-240. "Among the many Eastern thoughts, there is a realm of Javanese thought. As a culture, Java has various values which later become the cultural system of Javanese culture itself. These values are then expressed in various elements of Javanese culture which are manifested in the form of artifacts, social systems, and cultural systems. One of these values is 
found in one of the daily expressions of the Javanese people, namely "dikena iwake aja nganti butheg banyune". This expression seems very simple indeed, but it is full of various meanings, one of which is related to environmental ethics. This paper will attempt to describe the environmental ethics implied in this expression as an alternative solution to the problem of "tension" between the economy and ecology of the contemporary era, "pages 240-241.

The language style in this book is written in language that is easily understood by the audience (readers). Although several words use regional languages, the meaning of the language is explained in detail so that the reader can understand the meaning of the language. This book has a size of $15.5 \times 23 \mathrm{~cm}$ with a total page of 305 pages. Although this book is thick, it is very easy to carry around and not too heavy. In the book, the author does not ignore the facts or ideas of each chapter discussed. Because in this book the author describes each subject in detail from each different theme, so that readers can know the meaning or description of each chapter discussed in this book. So that every idea and fact is conveyed in this book clearly and in moderation.

The book has many advantages, so it is very interesting to read and to review because the author aims to help answer the problems and problems that we have always questioned in our minds. The book invites us to always think critically about everything that happens around us. In addition, the book also provides very useful information about how we can always appreciate all the differences that exist amid problems in society.

Even though the local cultural wisdom is that there are several regional languages that not everyone understands, the author describes the meaning of the language in detail, so that the reader can easily understand the meaning of the language. The book is very good to read because it contains various information that we rarely think about so far. In addition, the book also helps provide answers to problems that are philosophically happening in society. What is presented in this book can be useful and meet the expectations of all parties, especially those who serve science.

Antea Helonia Efendi \& Moses Glorino Rumambo Pandin Universitas Airlangga

\section{Reference :}

Hidayatullah, Syarif., \& Z. R. S, Abdul, dkk. (2020). Filsafat Dan Kearifan Dalam Agama Dan Budaya LOkal. D.I. Yogyakarta: Gadjah Mada University Press. 